\title{
The Potential Use of Indigobush (Amorpha fruticosa L.) as Natural Resource of Biologically Active Compounds
}

\author{
Tamara Jakovljević ${ }^{1 \unlhd}$, Jasna Halambek ${ }^{2}$, Kristina Radošević ${ }^{2}$, \\ Karla Hanousek 1, Marija Gradečki-Poštenjak ${ }^{3}$, Višnja Gaurina Srček ${ }^{2}$, \\ Ivana Radojčić Redovniković ${ }^{2}$, Alessandra De Marco ${ }^{4}$
}

${ }^{1}$ Croatian Forest Research Institute, Division for Forest Ecology, Cvjetno naselje 41, HR-10450 Jastrebarsko, Croatia

2 University of Zagreb, Faculty of Food Technology and Biotechnology, Department of Biochemical Engineering, Laboratory for Cell Culture Technology, Application and Biotransformations, Pierottijeva 6, HR-10000 Zagreb, Croatia

${ }^{3}$ Croatian Forest Research Institute, Division for Genetics, Forest Tree Breeding and Seed Husbandry, Cvjetno naselje 41, HR-10450 Jastrebarsko, Croatia

${ }^{4}$ ENEA, Italian National Agency for New Technologies, Energy and Sustainable Economic Development, Lungotevere Thaon di Revel 76, I-00196 Rome, Italy

$\triangle$ Corresponding author: e-mail: tamaraj@sumins.hr

Citation:

JAKOVLEVIĆ T, HALAMBEK J, RADOŠEVIĆ K, HANOUSEK K, GRADEČKI POŠTENJAK M, GAURINA SRČEK V, RADOJČIĆ REDOVNIKOVIĆ I, DE MARCO ALESSANDRA 2015 The Potential Use of Indigobush (Amorpha fruticosa L.) as Natural Resource of Biologically Active Compounds. South-east Eur for 6 (2): 171-178. DOI: http://dx.doi.org/10.15177/seefor.15-13

\section{Abstract}

Background and Purpose: Recent research indicates that a weed like Indigobush (Amorpha fruticosa L.) gives great opportunities for its commercialization through a rich spectrum of its beneficial biological features with possible use in the forestry and biotechnology field. Therefore, in this study we wanted to explore some of potential application of Indigobush extract, as a source of biologically active compounds, for animal cell culturing as well as green corrosion inhibitors.

Materials and Methods: The effect of ethanol extract of Indigobush seeds was studied on human tumor cell lines (HeLa and MCF-7) and cell viability was determined by WST-1 method after 72 hours of treatment with 6 different extract concentrations $\left(0.5-10 \mathrm{mg} \cdot \mathrm{mL}^{-1}\right)$. The inhibition effect of Indigobush seeds extract on the corrosion of aluminum in $0.5 \mathrm{M}$ hydrochloric acid solution was investigated by potentiodynamic polarization and electrochemical impedance spectroscopy (EIS) methods.

Results: Results showed that the addition of Indigobush extract had a stimulatory effect on MCF-7 cells growth at the concentrations $>1 \mathrm{mg} \cdot \mathrm{mL}^{-1}$ while the same effect on HeLa cells was observed only 
at the highest concentration of Indigobush extract $\left(10 \mathrm{mg} \cdot \mathrm{mL}^{-1}\right)$. The stimulatory effect of Indigobush extract on cell viability was more pronounced when the cells were grown in a medium with $5 \%$ FBS compared to $10 \%$ FBS (v/v). Indigobush extract did not show cytotoxic effect on MCF-7 and HeLa cells. Electrochemical studies showed that with increasing extract concentrations $\left(2.5-15 \mathrm{mg} \cdot \mathrm{mL}^{-1}\right)$ the values of corrosion current densities decrease, while the polarization resistance values increase. The maximum inhibition efficiency of Indigobush extract is reached at concentration of $15 \mathrm{mg} \cdot \mathrm{mL}^{-1}$ (82.9\%).

Conclusions: The Indigobush ethanol extract has no cytotoxic effect on human tumor cell lines MCF7 and HeLa. Results confirmed that extract originated from Indigobush has the potential to utilize for the mammalian cell culture media formulation by replacing the animal serum. Furthermore, data indicates that Indigobush extract has potential as green alternative to existing synthetic corrosion inhibitors.

Keywords: Indigobush, biologically active compounds, in vitro cell growth, green corrosion inhibitors

\section{INTRODUCTION}

Indigobush (Amorpha fruticosa L.) belongs to the genus of deciduous shrubs and semishrubs (Amorpha L.) from the Fabaceae family. The range of its natural habitat is from southern Canada to Mexico. It was introduced to Europe in the first half of $18^{\text {th }}$ century. In Croatia it is present since the beginning of $20^{\text {th }}$ century in the valleys of the rivers Sava, Drava and Kupa in the lowland oak forests. According to the recent investigation Indigobush is the most common in Posavina region [1]. It is an upright shrub which can reach 3 meters in height and spread to twice that in width. The leaves are pinnately compound. The violet flowers that appear in June-July are in upright narrow racemes that can be clustered or solitary. The fruits are tiny warty pods, each containing one seed. It tolerates poor site conditions, prefers neutral, low-acid and low-alkaline soils. It can grow in semi-shade or no shade and requires moist soil, so it can be found along riversides and streams from where its seed spread by water, especially floods. Because of its quick and rich growth it rapidly conquers forest habitats as weed species, and is often a limiting factor for forest regeneration. It forms a dense shrub level in the shade of the old oak and ash trees and competes with young plants for water and nutrients [2]. Because of that Indigobush is considered as an undesirable species in forestry, but recent research indicates that it is a plant of potentially great significance from economic aspect. It can be used for making blue dye, insecticides, repellents, perfumes, margarines and spices. Dense bushes make good cover for the animals and its twigs can be used for making flower arrangements and baskets. The great value of Indigobush is in its oil which can be used as biofuel and, if refined, as edible oil. The apiarist worship Indigobush as a rich honey producing crop [3]. With its root system preserve the soil from erosion as dense bushes planted in lines are making excellent protection against wind. In the USA, Indigobush is cultivated as decorative bush. Indigobush biomass research and its potentially bioenergetics value are extremely interested for the economy [1]. Indigobush seed is extremely viable and doesn't show any indications of germination loss, neither the viability loss during the storage. The results of germination tests of fresh seed imply at the phenomenon of seed dormancy due to the tightness of the seed shell [4].

The plants and their extracts have long been recognized to provide a potential source of chemical compounds or more commonly products known as phytochemicals with potent biological activity. Although leaves, roots, flowers, whole plants and stems were examined for useful phytochemicals in many studies, few reports refer to seeds as source for phytochemicals. Yet, a large number of chemical compounds are present in seeds or 
seed coats, including alkaloids, lectins and phenolic compounds [5]. Also, Indigobush as a promising reservoir for biologically active compounds has been recognized and studied in recent years. Published studies indicate the presence of various phenolic compounds in the Indigobush extracts. Three different isoflavones and five rotenoides were purified from Indigobush. The Indigobush beans gland contains about $3.5 \%$ of oil which is composed of various terpenes. The Indigobush seed is composed of fatty acids including linoleic, oleic, palmitic and stearic acid [6-8]. In 1943 glycoside amorphin, which is applied as a drug for nerve and heart disease, was isolated from Indigobush fruits [1]. According to Zheleva-Dimitrova [9], Indigobush extract shows antioxidant activity and could be useful in therapy of free radical pathologies and neurodegenerative disorders. Despite the fact it contains so many useful substances, Indigobush is mainly used for erosion control and to restore wasteland.

In this study, we wanted to explore some of potential application of Indigobush extract, as a source of biologically active compounds, for animal cell culturing as well as green corrosion inhibitors. Effects of ethanol extract of Indigobush on the viability of human tumor cell lines (HeLa and MCF-7) as well as possibility of partial substitution of animal serum with extract of Indigobush were studied. Also, the inhibition effect of Indigobush extract on the corrosion of aluminum in $0.5 \mathrm{M}$ hydrochloricacid solution was investigated by potentiodynamic polarization and electrochemical impedance spectroscopy (EIS) methods.

\section{MATERIALS AND METHODS}

\section{Indigobush (Amorpha fruticosa L.) Et- hanol Extract Preparation}

Seeds were collected in natural stand of Indigobush on the area of Forest office Sunja, Forest administration Sisak in 2012. The seeds were ground to fine powder and extracted with $300 \mathrm{~mL}$ of $96 \%$ ethanol at the reflux temperature for 2 hours. The crude extract $\left(0.05 \mathrm{~g} \cdot \mathrm{mL}^{-1}\right)$ was then filtered through filter paper. For determination of biological activity of extract, aliquot was taken, sterile filtered $(0.22 \mu \mathrm{m})$ and stored at $-20^{\circ} \mathrm{C}$ before use.

\section{Cell Lines and Culture Conditions}

Human tumor cell lines MCF-7 (breast adenocarcinoma; ATCC: HTB-22) and HeLa (cervical carcinoma; ATCC: CCL-2), purchased from American Type Culture Collection (ATCC) were cultured in $25 \mathrm{~cm}^{2}$ T-flasks in Dulbecco's Modified Eagle's Medium (DMEM, Gibco, UK) supplemented with 5 or $10 \%(\mathrm{v} / \mathrm{v})$ fetal bovine serum (FBS, Gibco, UK) and maintained in a humidified atmosphere of $5 \% \mathrm{CO}_{2}$ at $37^{\circ} \mathrm{C}$.

\section{Cytotoxicity Assay}

The effect of Indigobush extract on human tumor cells proliferation and viability was examined by the WST-1 assay (Roche, Germany) which is a modification of the classical MTT test [10]. MCF-7 and HeLa cells from the exponential growth phase were trypsinized and plated out in 96-well plates at initial concentration of $5 \times 10^{4}$ cells $\mathrm{mL}^{-1}(100 \mu \mathrm{L}$ cell suspension), allowed to attach for $24 \mathrm{~h}$. After that, MCF-7 and HeLa cells were exposed to sterile Indigobush ethanol extract for $72 \mathrm{~h}$. The range of applied nominal concentrations (0.5- $10 \mathrm{mg} \cdot \mathrm{mL}^{-1}$ ) was obtained by adding different volumes (1-20 $\mu \mathrm{L} /$ well) of Indigobush ethanol extract $\left(0.05 \mathrm{~g} \cdot \mathrm{mL}^{-1}\right)$. Since ethanol was used for Indigobush seed extraction, 96\% ethanol was added to the control. Morphology, general condition and number of the cells were assessed using Trypan blue exclusion method [11]. Following exposure, $5 \mu \mathrm{L}$ of tetrazolium salt WST-1 was added to each well and cells were incubated for further $3-4 \mathrm{~h}$ at $37^{\circ} \mathrm{C}$. The absorbance was measured at $450 \mathrm{~nm}$ on the microplate reader (Tecan, Switzerland). The experiments were performed three times with six parallels for each extract concentration. Cell viability was presented as percentage of control cells according to expression:

Cell viability $(\%)=[($ mean value $\mathrm{A} 450$ (sample) $/$ mean value $\mathrm{A} 450$ (control)] x 100 


\section{Evaluation of Anticorrosion Properties}

Corrosion tests were performed using coupons prepared from $99.85 \%$ pure aluminum. A specific volume of prepared extract was taken and added directly to $0.5 \mathrm{M} \mathrm{HCl}$ solution to prepare the desired concentrations in range from 2.5-15 $\mathrm{mg} \mathrm{mL}^{-1}$.

Electrochemical measurements were carried out in a conventional three electrode cylindrical glass cell using Potentiostat type VersaSTAT 3 (Princeton Applied Research), controlled by a personal computer. A saturated calomel electrode (SCE) and graphite electrode were used as reference and auxiliary electrodes, respectively. The working electrode was cut from aluminum and had a surface of $1 \mathrm{~cm}^{2}$. Before measurements the working electrode was abraded with emery paper to a 1200 metallographic finish, rinsed with distilled water and acetone. The all electrochemical measurements were performed in the test solution after reaching the open-circuit potential $\left(\mathrm{E}_{\text {ocp }}\right)$. Potentiodynamic polarization studies were performed at scan rate of $0.5 \mathrm{mV} \cdot \mathrm{s}^{-1}$ in the potential range from $\pm 150 \mathrm{mV}$ with respect to the $E_{\text {ocp }}$. All reported potentials refer to SCE. Electrochemical impedance spectroscopy (EIS) measurements were performed in the frequency range from $100 \mathrm{kHz}$ to $10 \mathrm{mHz}$ with an AC voltage amplitude perturbation of $5 \mathrm{mV}$. Inhibition efficiency $\left(\eta_{\mathrm{PP}}(\%)\right)$ is calculated using the equation:

$$
\eta(\%)=\frac{l_{\text {corr }}-l_{\text {corr }}^{\prime}}{l_{\text {corr }}} \times 100
$$

where $I_{\text {corr }}$ and $I_{\text {corr }}^{\prime}$ are the corrosion current densities in the absence and presence of inhibitor [12]. While the inhibition efficiency obtained from EIS measurements $\left(\eta_{\text {EIS }}(\%)\right)$ is calculated using the equation:

$$
\eta(\%)=\frac{R_{c t}^{\prime}-R_{c t}}{R_{c t}^{\prime}} \times 100
$$

where $\mathrm{R}_{\mathrm{ct}}^{\prime}$ and $\mathrm{R}_{\mathrm{ct}}$ are charge transfer resistance with and without inhibitor, respectively [12].

\section{RESULTS AND DISCUSSION}

\section{Cytotoxic Effects of Indigobush Extract in MCF-7 and HeLa Cells}

To evaluate cytotoxicity of Indigobush ethanol extract on human tumor cell lines MCF-7 and HeLa following $72 \mathrm{~h}$-exposure we used WST1 cell proliferation assay. The effect of different extract concentrations on both human tumor cell lines, expressed as a percentage of control, are summarized and shown in Figure 1.

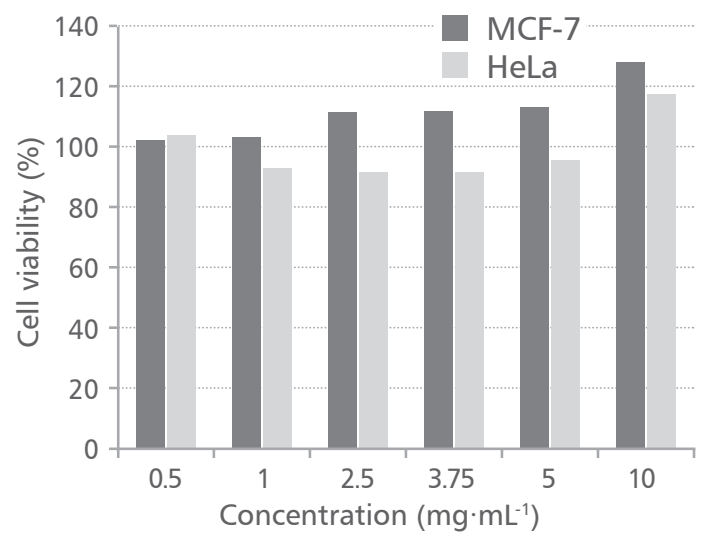

FIGURE 1. Effect of Indigobush ethanol extract on MCF-7 and HeLa cells after $72 \mathrm{~h}$ of exposure using WST-1 assay

Results showed that the addition of Indigobush extract had stimulatory effect on MCF-7 cells growth at the extract concentrations higher than $1 \mathrm{mg} \cdot \mathrm{mL}^{-1}$. There was no stimulatory effect on HeLa cells, except at the highest concentration of Indigobush extract $\left(10 \mathrm{mg} \cdot \mathrm{mL}^{-1}\right)$. Similarly, the positive effect on the growth of human T-cells (approximately $+15 \%$ ) was observed with the addition of $0.5 \mathrm{~g} \cdot \mathrm{L}^{-1}$ of selected Indigobush fruit extracts compared to the control [8]. In the same study, the methanol fruit extract of Indigobush showed relatively low cytotoxicity of $19 \%$ at a maximum concentration of $1 \mathrm{~g}^{\cdot \mathrm{L}^{-1}}$ in normal human lung cell line (HEL299). Despite relatively high tested concentration of the extract $\left(10 \mathrm{mg} \cdot \mathrm{mL}^{-1}\right)$, in our study, cytotoxic effect on both human tumor cell lines was not observed. 
Since the positive effect of Indigobush extract on MCF-7 and HeLa cells growth was observed, we were interested in whether the effect will be visible when cells were cultured at reduced volume of serum (5\%). Therefore, we established experiment where the cells were plated in medium with $5 \%$ and $10 \%$ of FBS. After $24 \mathrm{~h}$ cells were treated with $10 \mathrm{mg} \cdot \mathrm{mL}^{-1}$ of Indigobush extract since that concentration caused the most pronounced growth stimulation of MCF-7 and HeLa cells. The cell viability was determined by WST-1 assay after $72 \mathrm{~h}$ of exposure. The results are shown in Figure 2.

Results showed that the stimulatory effect of Indigobush extract on cell viability is more pronounced when the cells were grown in a

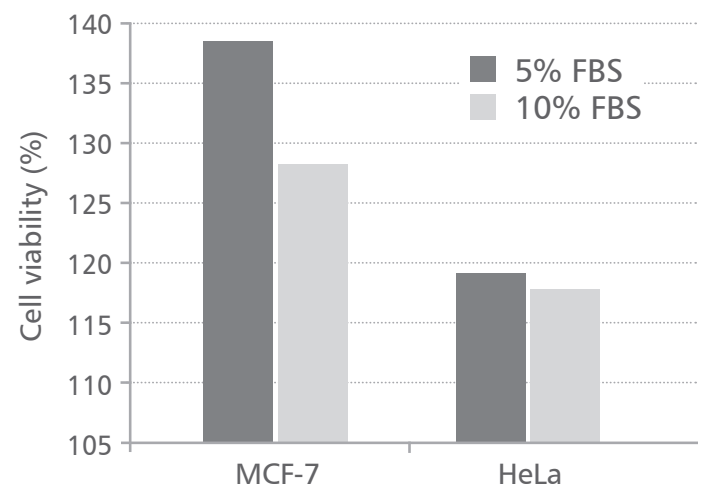

FIGURE 2. Effect of Indigobush extract (10 $\left.\mathrm{mg} \cdot \mathrm{mL}^{-1}\right)$ at various volume fraction of serum ( $5 \%$ and $10 \%$ FBS)

medium with $5 \%$ FBS compared to $10 \%$ FBS $(\mathrm{v} / \mathrm{v})$. This difference is more significant for MCF7 than HeLa cells. Also, the stimulatory effect of Indigobush ethanol extract on cell viability is stronger on MCF-7 cells compared to HeLa cells, which may indicate the specificity of action with respect to the cell type. Obtained results provide useful information for the utilization of Indigobush extract as medium additive or as a substitute for serum since various plant components have been proposed to replace serum in mammalian cell cultures [13]. However, more extensive research will be required to determine the qualitative and quantitative composition of the Indigobush extract and its mechanism of action, as crude extract and individual fractions or pure components. Also, it would be interesting to prepare a hydrolyzate of the plant and to examine its effect on different cell lines, since such data are not available in the literature and contribute to changing attitudes towards Indigobush as harmful and useless plant species.

\section{Inhibition Effect of Indigobush Extract on Aluminum Corrosion}

Aluminum is widely used in many industries, such as, the production of heat exchangers, filters, various containers, printing plates etc. and often comes into contact with different aggressive media that can cause significant corrosion. The addition of corrosion inhibitors in aggressive media is one of the frequently used methods for corrosion protection. Nowadays, a new class of corrosion inhibitors with low toxicity and good efficiency are plant extracts, therefore the exploration of natural products of plant origin as an inexpensive and green corrosion inhibitors is an essential field of study [14-16]. One of the goals of this research was to investigate the effects of Indigobush extract as complex system on corrosion of aluminum in $0.5 \mathrm{M} \mathrm{HCl}$ solution. Corrosion parameters were performed by using electrochemical measurements (potentiodynamic polarization and electrochemical impedance spectroscopy) (Table 1 and Figure 3).

In acidic solutions the main anodic reaction is the dissolution of aluminum in the form of $\mathrm{Al}^{3+}$ aqueous complexes and their passage from the metal surface into the solution, while the main cathodic reaction is a reduction of hydrogen ions and evolution of hydrogen gas [17]. Therefore, the inhibitor can influence on either the anodic or the cathodic reaction, or both.

Potentiodynamic polarization curves obtained for aluminum in $0.5 \mathrm{M} \mathrm{HCl}$ solution in the absence and presence of various concentrations of Indigobush extract at $25^{\circ} \mathrm{C}$ are shown in Figure $3 a$. From this figure is evident that addition of Indigobush extract in $\mathrm{HCl}$ solution causes remarkable decrease in current densities 
TABLE 1. Electrochemical parameters obtained for aluminum in $0.5 \mathrm{M} \mathrm{HCl}$ solution in absence and presence of Indigobush extract at $25^{\circ} \mathrm{C}$

\begin{tabular}{ccccccc}
\hline $\begin{array}{c}\mathrm{C} \\
\left(\mathrm{mg} \cdot \mathrm{L}^{-1}\right)\end{array}$ & $\begin{array}{c}\mathrm{E}_{\mathrm{corr}} \\
(\mathrm{mV} \mathrm{SCE})\end{array}$ & $\begin{array}{c}\mathrm{I}_{\mathrm{corr}} \\
\left(\mathrm{mA} \cdot \mathrm{cm}^{-2}\right)\end{array}$ & $\begin{array}{c}\boldsymbol{\eta}_{\mathrm{PP}} \\
(\%)\end{array}$ & $\begin{array}{c}\mathbf{R}_{\mathrm{ct}} \\
\left(\Omega \cdot \mathrm{cm}^{2}\right)\end{array}$ & $\begin{array}{c}\mathrm{CPE} \\
\left(\mu \mathrm{F} \cdot \mathrm{cm}^{-2}\right)\end{array}$ & $\begin{array}{c}\boldsymbol{\eta}_{\text {EIS }} \\
(\%)\end{array}$ \\
\hline 0 & -861 & 0.662 & - & 59.1 & 69.0 & - \\
2.5 & -908 & 0.398 & 39.9 & 106.3 & 37.6 & 44.4 \\
5.0 & -893 & 0.245 & 63.0 & 153.4 & 26.1 & 61.5 \\
7.5 & -905 & 0.173 & 73.9 & 212.0 & 18.8 & 72.1 \\
10.0 & -914 & 0.132 & 80.1 & 231.4 & 17.2 & 74.5 \\
15.0 & -938 & 0.113 & 82.9 & 273.2 & 14.6 & 78.4 \\
\hline
\end{tabular}

c - nominal concentrations of Indigobush ethanol extract; $\mathrm{E}_{\text {corr }}$ - electrochemical corrosion potential; $\mathrm{I}_{\text {corr }}$ - corrosion current densities in the absence of inhibitor; $\eta_{\mathrm{pP}}$ - Inhibition efficiency; $R_{c t}$ - charge transfer rersistance without inhibitor; CPE - constant phase element; $\eta_{E I S}$ - inhibition efficiency obtained from EIS measurements

and shifts the corrosion potentials in cathodic direction.

Inhibition efficiency $\left(\eta_{p}(\%)\right)$ values increase with increasing extract concentration and reach a maximum value of $82.9 \%$ for addition of $15 \mathrm{mg} \cdot \mathrm{mL}^{-1}$ Indigobush extract.

The effects of different concentrations of Indigobush extract on the impedance behaviour of aluminum in $0.5 \mathrm{M} \mathrm{HCl}$ solution have been obtained and results are given as Nyquist plots in Figure $3 b$. By addition of inhibitor to the
$\mathrm{HCl}$ solution, the diameter of the capacitive loop enlarges, this means that the charge transfer resistance, $R_{c t}$ values increase and an improvement in corrosion resistance of aluminum in acid solution is achieved.

The calculated EIS parameters for aluminum in $0.5 \mathrm{M} \mathrm{HCl}$ solution containing different concentrations of Indigobush extract are also presented in Table 1.

Inspection of these parameters reveals that the charge transfer resistance, $R_{c t}$ values

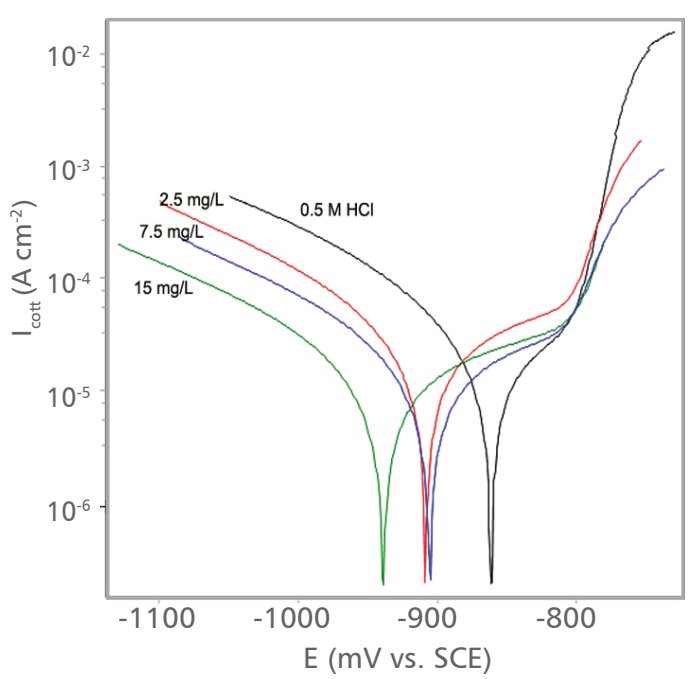

a)

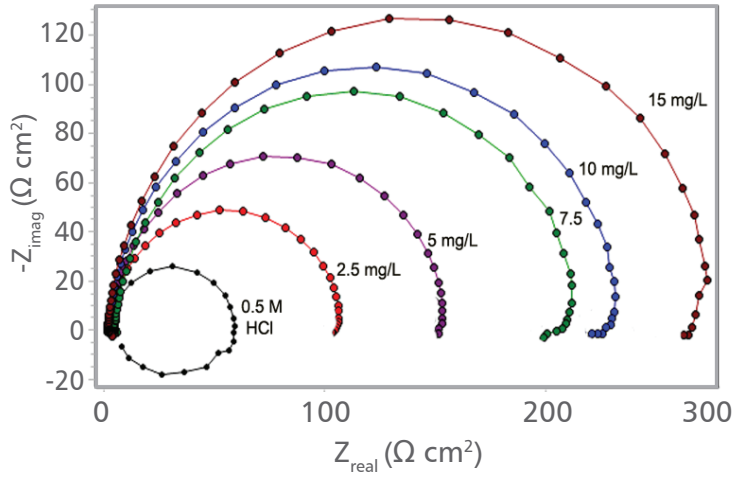

b)

FIGURE 3. Potentiodynamic polarization curves (a) and Nyquist plots (b) obtained for aluminum in 0.5 $\mathrm{M} \mathrm{HCl}$ solution in the absence and presence of Indigobush extract at $25^{\circ} \mathrm{C}$ 
increase, while CPE (constant phase element) decrease with the increasing concentration of Indigobush extract. The decrease of CPE values can result from an increase in the thickness of the electrical double layer and suggests the active molecule adsorption on aluminum surface. This also confirms that compact film of inhibitor is formed on the aluminum surface, which acting as a physical barrier for preventing the attack of the aggressive hydrochloric acid solution. This could be mainly attributed to the physical adsorption of active molecules present in Indigobush extract and adsorption process is possible because active molecules largely exist in the protonated form in acid solution. These protonated species can be adsorbed on the cathodic site of the aluminum decreasing the hydrogen evolution reaction.

Calculated inhibition efficiency values $\left(\eta_{\mathrm{EIS}}\right.$ (\%)) reach a maximum value in presence of $15 \mathrm{mg} \mathrm{L}^{-1}$ Indigobush extract (78.4\%) and they are quite similar whit efficiency values obtained by potentiodynamic polarization method.

Electrochemical results revealed that Indigobush extract is a good eco-friendly inhibitor for the corrosion control of aluminum in $0.5 \mathrm{M}$ hydrochloric acid.

Inhibition efficiency values increases with increasing Indigobush extract concentration, reaching a maximum value at concentration of
$15 \mathrm{mg} \cdot \mathrm{mL}^{-1}$ (82.9\%). Indigobush extract can be used as renewable and easily available inhibitor for aluminum corrosion.

\section{CONCLUSIONS}

These results confirmed that plant extracts originated from invasive plants like Indigobush can be used directly to develop new and effective classes of natural chemicals with potential application in various green technologies. This study will contribute to changing attitudes towards Indigobush as harmful and useless plant species.

Furthermore, results obtained in this study showed that Indigobush extract has the potential to utilize for the mammalian cell culture media formulation by replacing the animal serum and as green alternative to existing synthetic corrosion inhibitors. However, more extensive research will be required to determine the qualitative and quantitative composition of the Indigobush extract.

Within these challenges, screening native plants in general is useful for revealing antimicrobial, antioxidant activity and antitumor activity that may lead to the development of new products for use as nutritional and pharmaceutical agents.

\section{REFERENCES}

1. KRPAN APB, TOMAŠIĆ Ž, BAŠIĆ PALKOVIĆ P 2011 Biopotential of indigobusch (Amorpha fruticosa L.) - second year of investigation (in Croatian with English summary). Sumar List 135 (13): 103-112

2. DAT NT, LEE JH, LEE K, HONG YS, KIM YH, LEE JJ 2008 Phenolic Constituents of Amorpha fruticosa that Inhibit NF-kB Activation and Related Gene Expression. J Nat Prod 71 (10): 1696-1700. DOI: http://dx.doi.org/10.1021/np800383q

3. GLAVAŠ M 2009 Economic importance of Indigobush (Amorpha fruticosa L.). In: Krpan APB (ed) Book of Abstracts of Biological-Ecological and Energetic Characteristics of Indigobush (Amorpha fruticosa L.) in Croatia, Zagreb, Croatia, 12
March 2009. Croatian Forest Research Institute, Jastrebarsko, Croatia, pp 16

4. GRADEČKI POŠTENJAK M, LIOVIĆ B, NOVAK AGBABA S 2009 Qualitative properties of Indigobush seed (Amorpha fruticosa L.). In: Krpan APB (ed) Book of Abstracts of Biological-Ecological and Energetic Characteristics of Indigobush (Amorpha fruticosa L.) in Croatia, Zagreb, Croatia, 12 March 2009. Croatian Forest Research Institute, Jastrebarsko, Croatia, pp 31

5. BORCHARDT JR, WYSE DL, SHEAFFER CC, KAUPPI $\mathrm{KL}$, FULCHER RG, EHLKE NJ, BIESBOER DD, BEY RF 2009 Antioxidant and antimicrobial activity of seed from plants of the Mississippi river basin. J Med Plant R 3 (10): 707-718 
6. REISCH J, GOMBOS M, SZENDREI K, NOVAK I 1976 6a,12a-dehydro-a-toxicarol, ein neues potenoid aus Amorpha fruticosa. Phytochemistry 15: 234235

7. WANG BH, LEE SY 1974 Studies on the fatty acid composition of Amorpha fruticosa seeds. Korean J Foods Sci Technol 6 (2): 86-90

8. LEE HJ, KANG HY, KIM CH, KIM HS, KWON MC, KIM SM, SHIN IS, LEE HY 2006 Effect of new rotenoid glycoside from the fruits of Amorpha fruticosa LINNE on the growth of human immune cells. Cytotechnology 52 (3): 219-226. DOI: http:// dx.doi.org/10.1007/s10616-006-9040-5

9. ZHELEVA-DIMITROVA DZ 2013 Antioxidant and acetylcholinesterase inhibition properties of Amorpha fruticosa L. and Phytolacca americana L. Phcog Mag 9 (34): 109-113. DOI: http://dx.doi. org/10.4103/0973-1296.111251

10. MOSMANN T 1983 Rapid colorimetric assay for cellular growth and survival: application to proliferation and cytotoxicity assays. J Immunol Methods 65 (1-2): 55-63

11. FRESHNEY RI 1992 Animal Cell Culture: A Practical Approach. IRL Press, Oxford, UK, $329 p$

12. HALAMBEK J, BERKOVIĆ K 2012 Inhibitive Action of Anethum graveolens L. oil on Aluminium Corrosion in Acidic Media. Int J Electrochem Sci 7: 8356-8368
13. FARGES-HADDANI B, TESSIER B, CHENU S, CHEVALOT I, HARSCOAT C, MARC I, GEORGEN JL, MARC A 2006 Peptide fractions of rapeseed hydrolysates as an alternative to animal proteins in $\mathrm{CHO}$ cell culture media. Process Biochem 41 (11): 2297-2304. DOI: http://dx.doi.org/10.1016/j. procbio.2006.06.002

14. HALAMBEK J, CVJETKO BUBBALO M, RADOJČIĆ REDOVNIKOVIĆ I, BERKOVIĆ K 2014 Behaviour of Aluminium and AA5754 Alloy in 1\% Acetic Acid Solution in Presence of Laurel Oil. Int J Electrochem Sci 9: 5496-5506

15. HALAMBEK J, BERKOVIĆ K, VORKAPIĆ FURAČ J 2013 Laurus nobilis L. oil as green corrosion inhibitor for aluminium and AA5754 aluminium alloy in $3 \% \mathrm{NaCl}$ solution. Mater Chem Phys 137 (3): 788-795

16. HALAMBEK J, BERKOVIĆ K, VORKAPIĆ FURAČ J 2010 The influence of Lavandula angustifolia L. oil on corrosion of Al-3Mg alloy. Corros Sci 52 (12): 3978-3983. DOI: http://dx.doi.org/10.1016/j. corsci.2010.08.012

17. ŠERUGA M, HASENAY D 2001 Electrochemical and surface properties of aluminium in citric acid solution. J Appl Electrochem 31 (9): 961-967. DOI: http://dx.doi.org/10.1023/A:1017556323508 